Bangladesh J. Plant Taxon. 12(2): 1-9, 2005 (December)

\title{
ADDITIONS TO THE GENUS STIGEOCLONIUM (CHLOROPHYTA) AS NEW RECORDS FOR BANGLADESH
}

\author{
MaZibar Rahman KHAN ${ }^{1}$ AND A. K. M. NuRUl Islam \\ Department of Botany, University of Dhaka, Dhaka-1000, Bangladesh
}

Key words: New records, Stigeoclonium, Chlorophyta, Chaetophoraceae, Bangladesh

\begin{abstract}
Three taxa belonging to the genus Stigeoclonium (Chaetophorales, Chlorophyta) are described here as new records for Bangladesh, namely, Stigeoclonium amoenum var. novizelandicum, $S$. protensum and $S$. tenue var. uniforme.
\end{abstract}

\section{Introduction}

Thirty one taxa (23 species and 8 varieties) of Stigeoclonium (Family: Chaetophoraceae: Order: Chaetophorales) so far have been reported from Bangladesh (Islam 1963, 1972, Islam and Ahia 1964, Islam and Hossain 1978, Islam and Zaman 1975, Islam and Aziz 1979, Islam et al. 1979, Islam et al. 1980, Khan and Islam 1998,1999) and comprehensive ecological notes on these have been mentioned (Khan and Islam 1993). Of these taxa, seven were described as new to science (Islam 1972, Khan and Islam 1998). Further studies of the Chaetophoralean algae of Bangladesh revealed the presence of three more taxa of Stigeoclonium in Bangladesh, namely $S$. amoenum var. novizelandicum, $S$. protensum and $S$. tenue var. uniforme, which are now described in the present paper.

\section{Materials and Methods}

The materials for the study were collected from almost all the present districts of Bangldesh (for details see Khan 1992). The materials were preserved in Transeau's solution and kept in the Phycological Herbarium, Department of Botany, University of Dhaka. The localities and the ecological conditions of the habitats of the three taxa have been mentioned under each taxon described below.

\section{Taxonomic descriptions}

1. Stigeoclonium amoenum Kg. var. novizelandicum Nordst.

(Islam 1963, Sarma 1986)

(Pl. 1, Figs. 1-3; Pl. 2, Figs. 4-6, Pl. 3, Figs. 7-10)

Thallus light green, $2-5 \mathrm{~cm}$, long attached to the substratum by profuse rhizoids which are not much branched, mostly developing from one side, tips of the rhizoids swollen; erect part well developed, main axis consisting of short and long cells; branchproducing cells usually short, $11-15 \mu \mathrm{m}$ broad and 15-25 $\mu \mathrm{m}$ long; 2-3 short cells which branches forming node-like appearance, branches opposite, alternate and rarely forming pseudowhorls of 3-4; tips of branches usually pointed, often blunt, primary

${ }^{1}$ Department of Botany, Patuakhali Govt. College, Patuakhali, Bangladesh. 


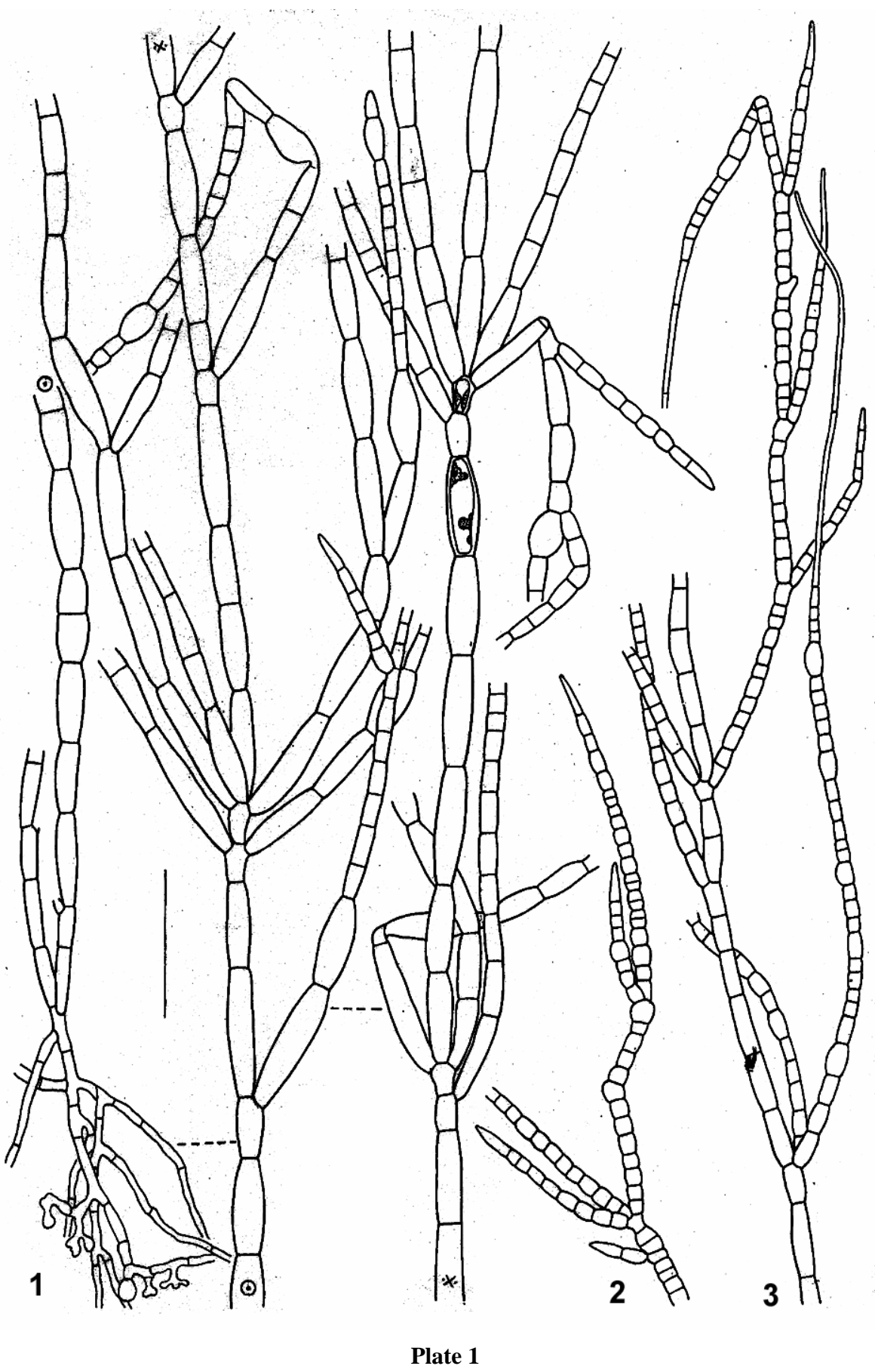

Figs. 1-3. Stigeoclonium amoenum var. novizelandicum (showing basal rhizoid part and erect part with branch habit and cell types; 2-3. apical branches with hairs; from Mirpur, Dhaka); Scale =100 $\mu \mathrm{m}$. 


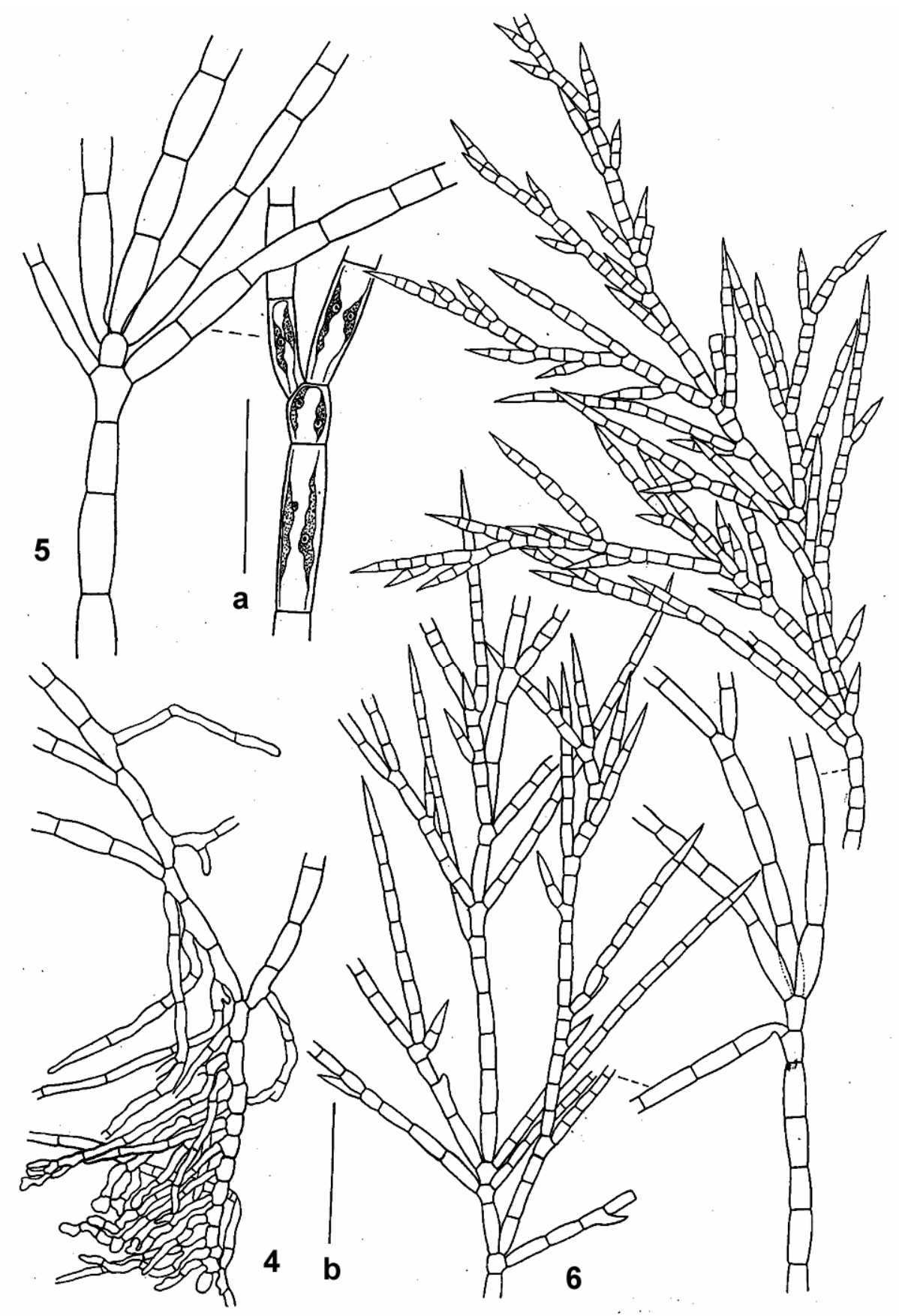

Plate 2

Figs. 4-6. Stigeoclonium amoenum var. novizelandicum (showing basal part with rhizoids, upper part showing branching habit and cell structure with chloroplast; from Kalikapur, Patuakhali); Scales: a=50 $\mu \mathrm{m} ; \mathrm{b}=100 \mu \mathrm{m}$. 


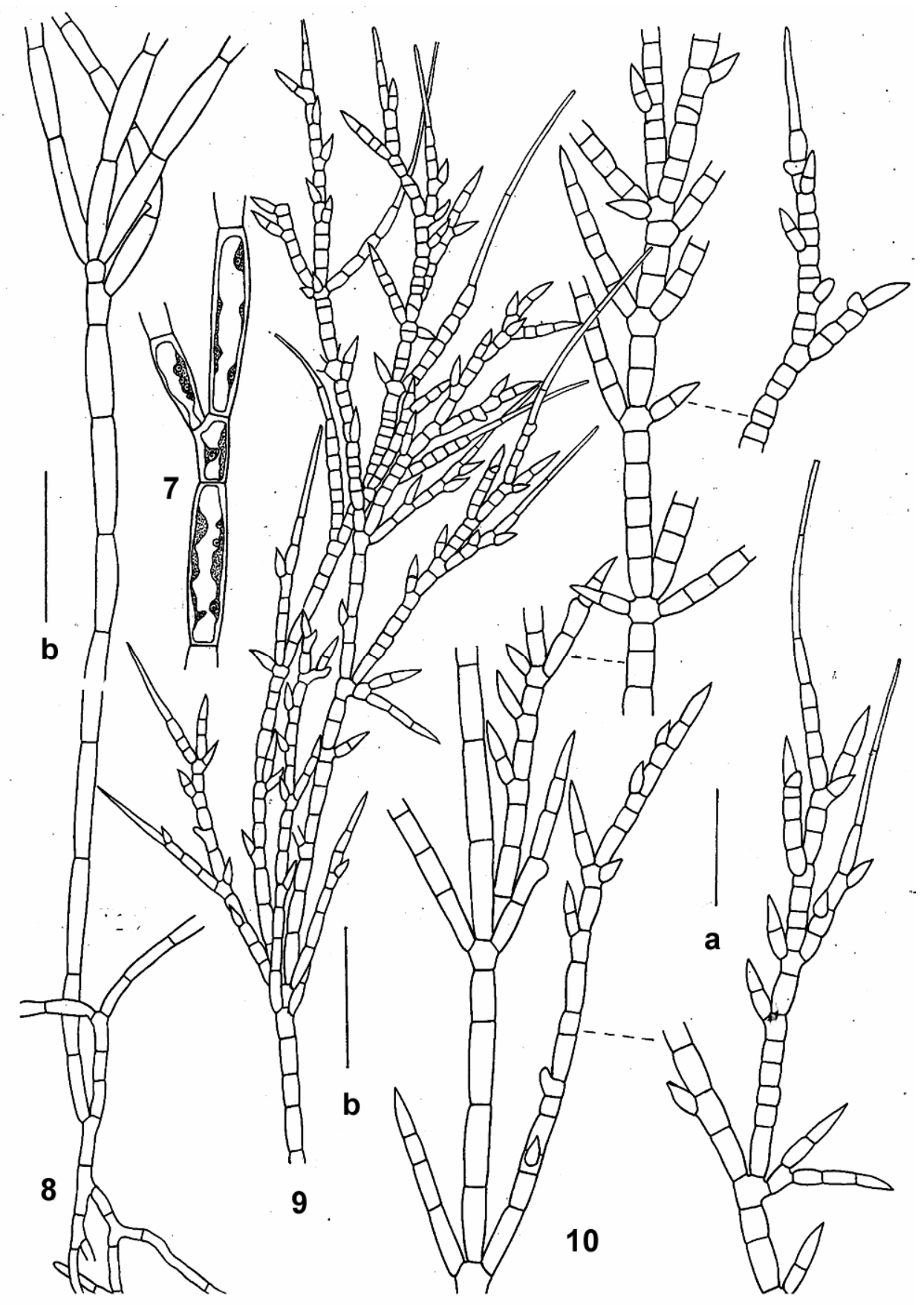

Plate 3

Figs. 7-10. Stigeoclonium amoenum var. novizelandicum (showing basal part with rhizoids and upper erect part showing chloroplast and branching habit and hairs; from Sonargaon, Narayanganj); Scales: $a=50 \mu \mathrm{m}$; $\mathrm{b}=100 \mu \mathrm{m}$. 
branches long and secondary branches short; cells of the main axis cylindrical, inflated at the middle with little constriction, 10-22 $\mu \mathrm{m}$ broad and 29-95 $\mu \mathrm{m}$ long; cells in some become swollen, bulbuous in shape mostly at the upper part of the branches (may be due to environmental factors or by the attack of chytrids; chloroplast single, parietal, with 1-5 pyrenoids.

Specimens studied: Narayanganj, Col. No. MR-228, 230, on the adventitious roots of deepwater rice plant and on the stem of Alternanthera sp., Kantal beel, Sonargaon, water temp. $31^{\circ} \mathrm{C}, \mathrm{pH}$ 6.7, 22.9.1986; Dhaka, MR-332, on adventitious roots and stems of rice plant, Nawab beel near Dhaka Zoo, water temp. $32^{\circ} \mathrm{C}, \mathrm{pH}, 6.7,27.5 .1987$; Patuakhali, MR-1676, on submerged bricks, road side ditch, town Kalikapur, water temp. $28^{\circ} \mathrm{C}$, $\mathrm{pH}$ 7.0, 24.9.1987.

This variety superficially resembles $S$. tenue in having branch-producing cells, short cells and apical cells with pointed tips but differs in having inflated and much elongated cells of the main axis and also in general appearance. The swollen bulbuous structures of the cells may be due to fungal infection (by chytrids).

\section{S. protensum (Dillw) Kg.}

(Pl. 4, Figs. 11-12)

(Heering 1914, Islam 1963)

Plants light green, mucilagenous, grown on submerged bricks, attached to the substratum by the rhizoids, $4-8 \mu \mathrm{m}$ in diameter; prostrate part not found; primary branches long drawn, branches mostly alternate, somewhat scattered, rarely opposite and often with whorl of three, most of the branches curved basal cells of which are swollen; branches tapering into multicellular setiferous hairs and others with blunt tips; cells of the main axis cylindrical, 9-12 $\mu \mathrm{m}$ broad and 11-36 $\mu \mathrm{m}$ long, often inflated, barrel-shaped, cells of the branches mostly barrel-shaped and sometimes cylindrical with little constriction, cell-wall thin, cells producing branches short or long; chloroplast single parietal with median band, consisting of 1-2 pyrenoids.

Specimen studied: Sirajganj, Col. No. MR-1247, on submerged bricks in a pond near Upazila Sadar, Tarash, water temp. $19^{\circ} \mathrm{C}$, pH 6.8, little polluted, 28.12.1986.

According to Islam (1963) this species is quite polymorphic and its growth forms resemble $S$. stagnatile. Bangladesh material looks like $S$. tenue but its long drawn setiferous terminal hairs, swollen basal cells of the branches, slightly inflated or barrel-shaped cells and median band chloroplast are the characteristic features of this species.

3. S. tenue (Ag.) Kg. var. uniforme (Ag). Kg.

(Pl. 5, Figs. 13-15)

(Islam 1963; Printz 1964 as S. uniforme (Ag.) Rab.; Sarma 1986)

Thallus dark green, 1-3 cm long, mucilagenous, differentiated into prostrate and erect system; prostrate cells mostly globular, 9-15 $\mu \mathrm{m}$ in diameter, often irregular in shape, filled with food materials; rhizoids developed mainly from the cells of the lower part of 


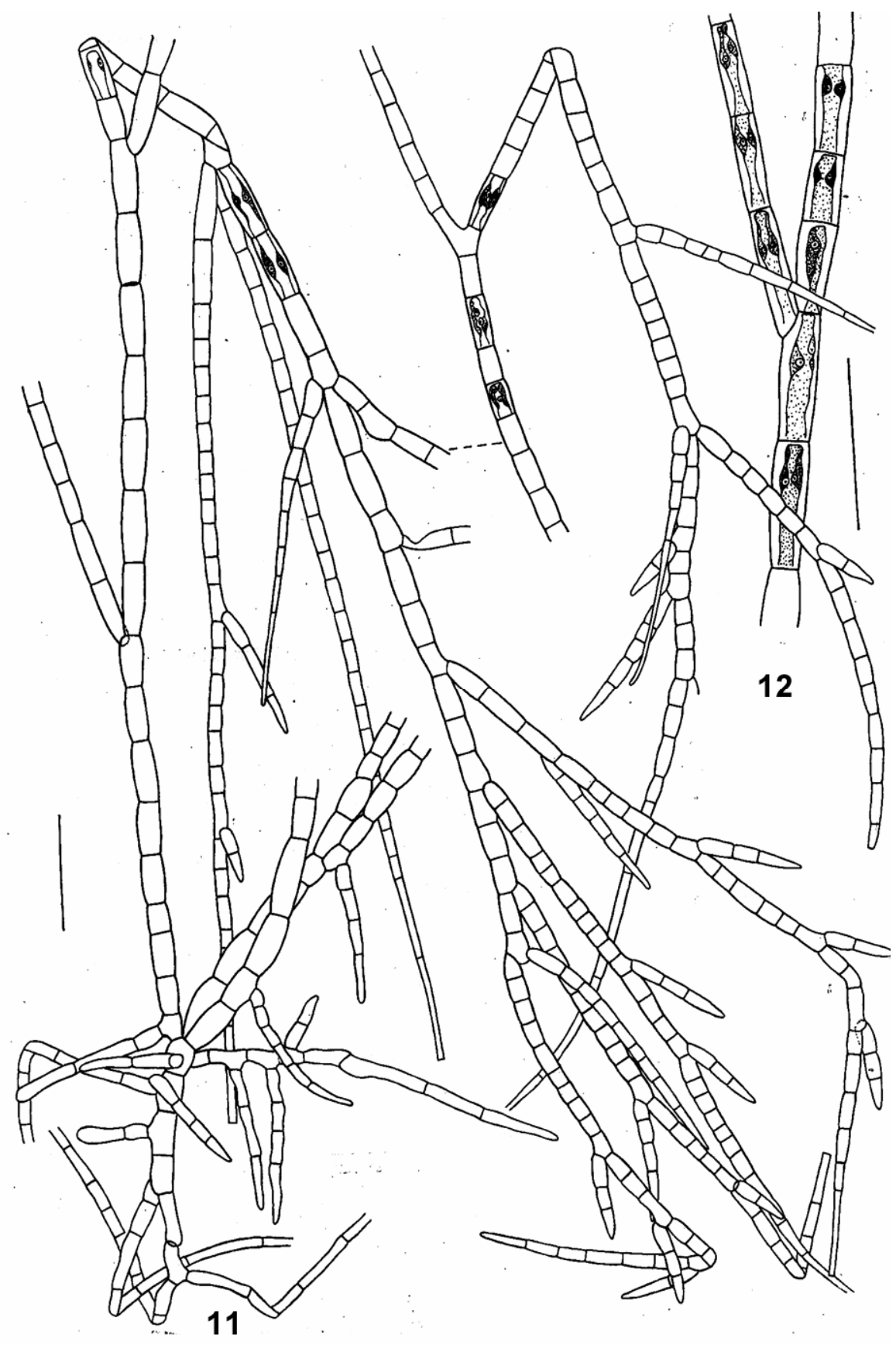

Plate 4

Figs. 11-12. Stigeoclonium protensum (showing basal part with rhizoids and erect part with branching habit and chloroplast); Scale $=50 \mu \mathrm{m}$. 


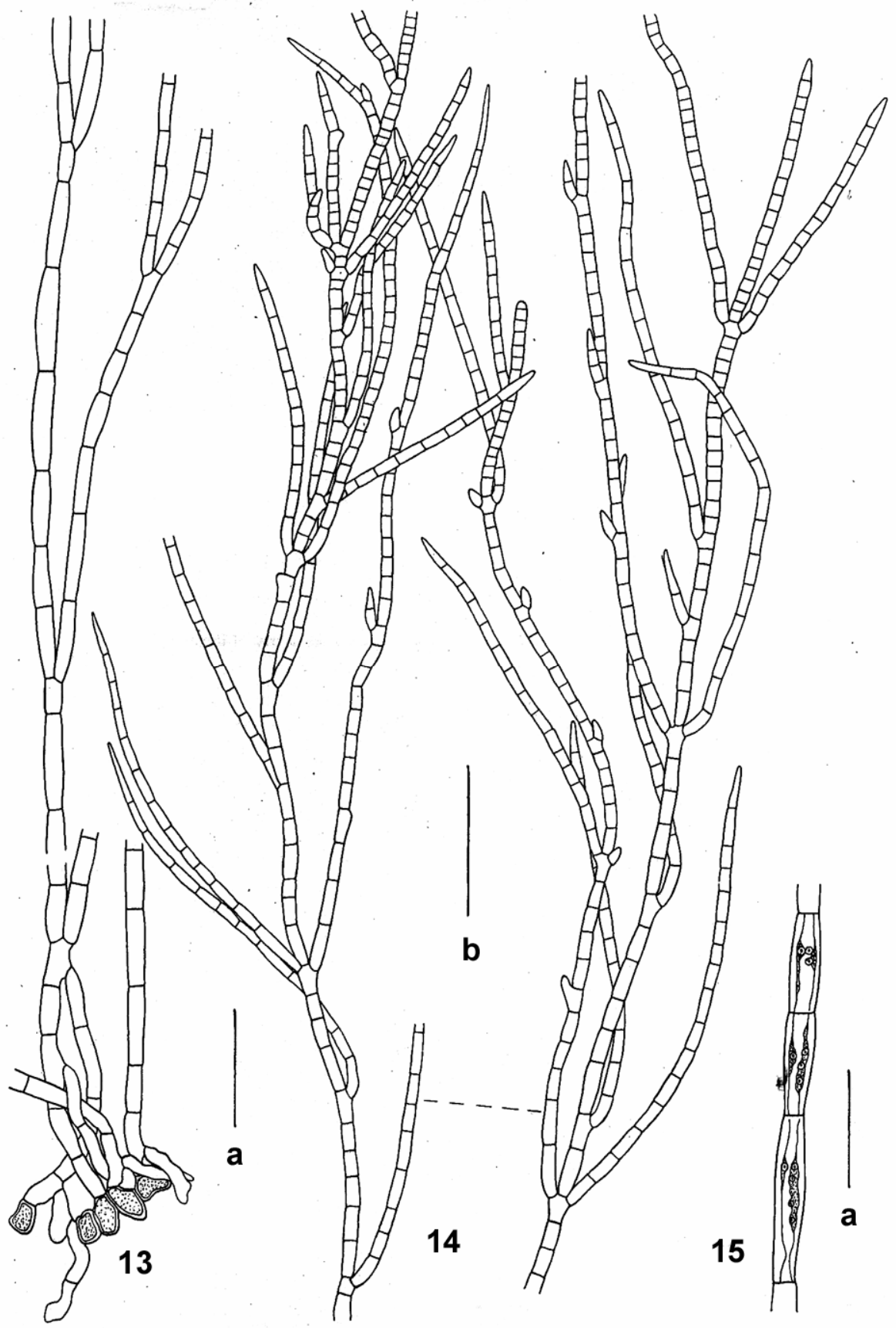

Plate 5

Figs. 13-15. Stigeoclonium tenue var. uniforme (showing prostrate part and erect part with long-drawn apical tufts; Scales: $\mathrm{a}=50 \mu \mathrm{m} ; \mathrm{b}=100 \mu \mathrm{m}$. 
the filaments, cells of the rhizoids 4.0-7.5 $\mu \mathrm{m}$ broad and 17-43 $\mu \mathrm{m}$ long; erect filaments profusely branched, branches alternate and opposite, no whorl formation, most of the branches developed from short cells, rarely from long cells, primary and secondary branches long and slender, crowded to form long drawn tufts, branches mostly with pointed tips; cells of the main axis cylindrical, 8-14 $\mu \mathrm{m}$ broad and 20-82 $\mu \mathrm{m}$ long, cellwall thin, branch-producing cells angular, cells longer at the base and short at the apex, some inflated at the middle; chloroplast girdle-shaped, with 2-5 pyrenoids.

Specimens studied: Natore, Col. No. MR-661, on the stem of Alternanthera sp. in a shallow pond near Registrar Office, Shingra, water temp. $23^{\circ} \mathrm{C}, \mathrm{pH} 7.0,24.12 .1986$; Thakurgaon, MR-843, on submerged bricks in Tangan river, water temp. $17^{\circ} \mathrm{C}, \mathrm{pH} 5.8$, 21.12.1986.

The variety is characterized mostly by the larger cells than the type and the formation of long plumose tufts at the tips of the branches and main filaments.

\section{Acknowledgement}

The first author is grateful to the Bangladesh University Grants Commission for awarding him a fellowship and to the Ministry of Education, Govt. of Bangladesh for granting him the study leave with deputation to carry out this work in the Department of Botany, University of Dhaka.

\section{References}

Heering, W. 1914. Ulotrichales, Microsporales, Oedogoniales. In: Pascher, A (ed.), Die Süsswasserflora Deuschlands, Osterreichs und der Schweiz, Heft 6, Chlorophyceae 3, Gustav Fischer, Jena, pp. 250.

Islam, A.K.M. Nurul. 1963. A revision of the genus Stigeoclonium Beih. z. Nova Hedwigia 10: 1-164 + pls. 1-47.

Islam, A.K.M. Nurul. 1972. New and rare species of some green algae from Bangladesh. Nova Hedwigia 23 : 655-663 + pls. 1-14

Islam, A.K.M. Nurul and Ahia, A.N.M. 1964. Contribution to the knowledge of Chaetophoraceae of Dacca district. Pak. J. Biol. Agr. Sci. 7(1): 103-110.

Islam, A.K.M. Nurul and Aziz, A. 1979. Algal flora of Moheshkhali Island. Bangladesh. Dhaka Univ. Stud. B. 27(2): 105-122.

Islam, A.K.M. Nurul and Hossain, S.K.T. 1978. Algal flora of the ablution tanks of mosques in Dacca city. J. Asiatic Soc. Bangladesh (Sci.) 3(2): 103-113.

Islam, A.K.M. Nurul, Anatunnesa and Haroon, A.K.Y. 1980. Hydrobiological studies in and around Naogaon, Rajshahi. Dacca Univ. Stud. B. 28(2): 3147.

Islam, A.K.M. Nurul, Rahman, M. and Choudhury, A.R. 1979. Hydrobiological studies of Dhanmondi lake, Dacca. 1. Macrophytes and benthic flora. J. Asiatic Soc. Bangladesh (Sci.) 5(1): 59-75.

Islam, A.K.M. Nurul and Zaman, K.M. 1975. Limnological studies of the river Buriganga. III. Biological aspect. J. Asiatic Soc. Bangladesh (Sci.). 1(1): 45-65.

Khan, M.R. 1992. Critical studies on the Chaetophoralean algae of Bangladesh. Ph. D. Thesis, University of Dhaka. pp. $363+$ pls. 1-169.

Khan, M.R. and Islam, A.K.M. Nurul. 1993. Ecology of Chaetophoralean algae of Bangladesh. J. Asiatic Soc. Bangladesh (Sci.). 19(2): 145-153. 
Khan, M.R. and Islam, A.K.M. Nurul. 1998. Six new taxa of Chaetophoraceae (Chlorophyta) from Bangladesh. Bangladesh J. Plant Taxon. 5(2): 13-27.

Khan, M.R. and Islam, A.K.M. Nurul. 1999. New records of Stigeoclonium taxa (Chlorophyta) for Bangladesh. Bangladesh J. Plant taxon. 6(2): 55-83.

Printz, H. 1964. Die Chaetaphoralen der Binnengewasser. Hydrobiol. 24(1/3): 1-576.

Sarma, P. 1986. The freshwater Chaetophorales of New Zealand. Beih. z. Nova Hedwigia 58: 1-169+ 550 figs. 